\title{
Effects of short-term variation in forage quality and forage to concentrate ratio on lactating dairy cows
}

\author{
P. S. Yoder, N. R. St-Pierre, K. M. Daniels, K. M. O'Diam, and W. P. Weiss ${ }^{1}$ \\ Department of Animal Sciences, Ohio Agricultural Research and Development Center, The Ohio State University, Wooster 44691
}

\section{ABSTRACT}

Within-farm variation in forage composition can be substantial and potentially costly, and it presents challenges for sampling the forage accurately. We hypothesized that day-to-day variation in forage neutral detergent fiber (FNDF) concentrations and diet variation caused by sampling error would have negative effects on production measures in lactating dairy cows. Twenty-four Holstein cows (73 d in milk) were used in 8 replicated $3 \times 3$ Latin squares with 21 -d periods. Treatments were (1) control $(\mathrm{CON}),(2)$ variable (VAR), and (3) overreacting (ORR). On average, over the 21-d period, all 3 treatments were the same [24.7\% FNDF and $48.2 \%$ forage dry matter (DM) composed of $67 \%$ alfalfa silage and $33 \%$ grass silage]. The CON treatment was essentially consistent day-to-day in total forage and FNDF concentrations and proportion of alfalfa and grass silages. The VAR treatment changed daily (in a random pattern) in proportion of alfalfa and grass silages fed, which resulted in day-today changes in FNDF (range was 21.5 to $28 \%$ ). The ORR treatment varied in a 5 -d cyclic pattern in total forage and FNDF concentrations $(26,24,28$, and $21.5 \%$ FNDF). Over the $21 \mathrm{~d}$, ORR $(25.1 \mathrm{~kg} / \mathrm{d})$ had higher DM intake compared with CON $(24.5 \mathrm{~kg} / \mathrm{d})$ and VAR $(24.3 \mathrm{~kg} / \mathrm{d})$. Milk production $(42.8 \mathrm{~kg} / \mathrm{d})$, milk fat $(3.5 \%)$, and milk protein $(2.8 \%)$ were not affected by treatment; however, a treatment $\times$ day interaction was observed for milk production. Lower daily milk yields for VAR and ORR compared with CON were rare; they only followed sustained 4- and 5-d periods of feeding higher FNDF diets compared with CON. In contrast, increased daily milk yields for VAR and ORR versus CON were more frequent and followed sustained diet changes of only 2 or $3 \mathrm{~d}$. Lipolytic and lipogenic-related enzyme mRNA abundances in subcutaneous adipose tissue were not affected by treatment. Treatment $x$ day interactions were observed for milk fatty acid markers of cellulolytic bacteria (iso-14:0, iso-15:0, iso-16:0)

Received February 22, 2013.

Accepted June 26, 2013.

${ }^{1}$ Corresponding author: weiss.6@osu.edu and lipolysis (18:0) and generally followed the expected response to changes in daily rations. Overall, extreme daily fluctuations in FNDF had no cumulative negative effect on production measures over a 21-d period, and daily responses to transient increases in FNDF were less than expected.

Key words: variation, forage neutral detergent fiber, milk fatty acid

\section{INTRODUCTION}

Within-farm variation in nutrient composition of forages can be substantial. On 8 commercial dairy farms over a 14-d sampling period, the average within-farm, day-to-day standard deviation and range for hay crop silage NDF were $2.4 \%$ and 8.5 percentage units, respectively (Weiss et al., 2012). Because forages usually have high dietary inclusion rates for lactating cows, the variation in forage composition could lead to substantial day-to-day variation in the composition of the TMR.

In high-producing dairy cows limited by physical fill, greater concentrations of forage NDF (FNDF) decrease DMI, $\mathrm{NE}_{\mathrm{L}}$ intake, and milk production (Allen, 2000). Reduced concentrations of FNDF result in the opposite response: increased DMI and milk production when effective fiber is adequate and starch concentrations are not excessive (Allen, 2000). However, these responses are usually measured in experiments lasting weeks. What is not known is the effect of short-term (i.e., daily) changes in diet FNDF and whether daily variation has cumulative effects on cows. Oscillating concentrations of dietary long-chain fatty acids reduced DMI and milk production but the response did not occur until cows were on treatment for about $8 \mathrm{~d}$ (Weiss et al., 2013). In contrast, oscillation of dietary CP had no negative short-term or cumulative negative effects on nutrient utilization or growth in beef cattle (Cole et al., 2003). The effects of day-to-day variation in concentrations of NDF or in forage quality on dairy cows are not known.

Another diet formulation issue related to feed variation is sampling. Obtaining a representative sample and determining, in a timely manner, whether the nutrient composition of a feed has indeed changed is 
difficult when the feed is highly variable (St-Pierre and Cobanov, 2007). A common approach to formulation is to use data from the most recent sample without considering potential sampling and analytical errors and without consideration of previous data from that feed. The new sample is treated as if it represents a new population, thus resulting in reformulation of the diet using the new data. This can result in overreaction (i.e., changing the diet formulation when the ingredient composition actually did not change), causing the TMR to vary in a pattern reflecting diet reformulation.

Based on field observations, day-to-day variation in diet composition is thought to be detrimental to milk production and farm profitability (Barmore and Bethard, 2005). We hypothesized that substantial day-to-day variation in diet FNDF would (1) decrease DMI and milk production and (2) affect partitioning of nutrients in mid-lactation dairy cows. We also hypothesized that variation imposed by diet reformulation in response to unrepresentative samples would have similar negative effects.

\section{MATERIALS AND METHODS}

All procedures involving animals were approved by The Ohio State University Institutional Animal Care and Use Committee. Twenty-four Holstein cows were blocked into groups of 3 by parity ( 2 blocks of primiparous and 6 blocks of multiparous) and milk production (multiparous cows only) and randomly assigned to 1 of 3 treatment sequences in 8 orthogonally replicated $3 \times$ 3 Latin squares. Four squares started the experiment together (group 1) and a second group of 4 squares started the experiment $21 \mathrm{~d}$ later (group 2). Period length was $21 \mathrm{~d}$ and the entire experiment was completed in $84 \mathrm{~d}$. All cows were moved into a tiestall barn and fed the control diet for $7 \mathrm{~d}$ before starting the experiment. At the beginning of the experiment, BW and DIM averaged $645 \mathrm{~kg}(\mathrm{SD}=64 \mathrm{~kg})$ and $73 \mathrm{~d}(\mathrm{SD}=$ $11 \mathrm{~d})$. Cows were housed in individual tiestalls, fed once daily for ad libitum consumption, and milked twice daily (0200 and $1300 \mathrm{~h}$ ); milk weights were recorded. Diets were fed as a TMR at approximately $0300 \mathrm{~h}$ for a target of $5 \%$ refusals. Actual refusals averaged $4.1 \%$ across all cows and days. Cows were weighed on 2 consecutive days before the experiment and on the last $2 \mathrm{~d}$ of each period. Cows were body condition scored $(1=$ emaciated; $5=$ obese) by 3 independent people (scores averaged within cow-period) at the beginning of the experiment and on d 21 of each period.

Treatments were control $(\mathbf{C O N})$, variable (VAR), and overreacting (ORR). On average, all diets were identical in nutrient concentrations to $\mathrm{CON}$ over the 21-d periods. The average diet (CON) was formulated using NRC (2001) for $41 \mathrm{~kg}$ of $\mathrm{NE}_{\mathrm{L}}$-allowable milk and $45 \mathrm{~kg}$ of MP-allowable milk with $9.8 \% \mathrm{RDP}$ and $6.9 \%$ RUP. The CON diet contained 2 different alfalfa silages: a grass silage and a corn grain-based concentrate mix (Tables 1 and 2). The grass silage was composed mostly of mature orchardgrass (Table 3). Two independent alfalfa silages stored in separate Harvestore silos (Engineered Storage Products Company, DeKalb, IL) were used to reduce the variation in alfalfa silage composition (Table 3). Altering the proportion of alfalfa to grass silage was used to produce the desired day-to-day changes in diet forage composition and FNDF concentrations.

The CON diet was formulated to have a constant $24.7 \%$ FNDF from day to day with essentially constant alfalfa:grass and forage:concentrate ratios (Table 1, Figure 1). The VAR diet was designed to be variable in FNDF concentration from day to day but to average $24.7 \%$ FNDF over $21 \mathrm{~d}$ (Table 2, Figure 2). The FNDF concentration was varied by changing the proportion of alfalfa and grass silage, but the forage to concentrate ratio was held constant. Daily inclusion rates of alfalfa and grass silages were determined randomly via Monte Carlo uniform distribution simulation before the experiment, and the resulting daily FNDF concentration pattern was repeated each period. The variance used in the simulation was based on variation in silage NDF concentrations measured on commercial dairy farms (Weiss et al., 2012).

Over each 21-d period, the forage to concentrate ratio for ORR changed 4 times, but on average the diet was $24.9 \%$ FNDF and had the same forage to concentrate ratio as CON. The ratio of grass to alfalfa was held constant for ORR (Table 1, Figure 1). The ORR mimicked variation that could be caused by using data from unrepresentative samples (i.e., a change in NDF was observed but the silage NDF did not really change). The diet was reformulated using the hypothetically erroneous silage NDF sample results with the goal of maintaining a constant FNDF. Because the silage NDF really did not change, actual FNDF concentrations changed instead. On d 1 to $\mathrm{d} 5$, the forage percentage of the ORR diet was higher than that of CON and represented formulating a diet with a lower than actual NDF silage sample result. On d 6 to 10, the forage percentage of the ORR diet was lower than that of $\mathrm{CON}$ and represented formulating with a higher than actual NDF silage sample. On d 11 to 15 and d 16 to 20, a lower than actual and a higher than actual NDF sample result, respectively, were used, which resulted in a higher and lower forage percentage of the formulated diet compared with CON. 
Table 1. Average (over $21 \mathrm{~d}$ ) ingredient composition of diets (\% of DM) $)^{1}$

\begin{tabular}{lccc}
\hline Item & CON & VAR & ORR \\
\hline Alfalfa silage A & 21.2 & 21.6 & 21.4 \\
Alfalfa silage B & 11.0 & 10.2 & 10.8 \\
Grass silage & 16.1 & 16.1 & 16.2 \\
Corn grain, ground & 35.2 & 35.4 & 35.1 \\
Dried distiller grains with solubles $_{\text {Corn gluten meal }}$ & 4.10 & 4.12 & 4.09 \\
Treated soybean meal $^{2}$ & 3.60 & 3.62 & 3.59 \\
Soybean meal, 48\% CP $_{\text {Soybean hulls }}$ & 2.91 & 2.93 & 2.90 \\
Fat, animal-vegetable blend $_{\text {Tallow }}$ & 0.88 & 0.89 & 0.88 \\
Limestone $_{\text {Trace mineral salt }}$ & 1.73 & 1.73 & 1.72 \\
Dicalcium phosphate $_{\text {Magnesium oxide }}$ & 0.96 & 0.96 & 0.95 \\
Trace mineral-vitamin premix $^{3}$ & 0.48 & 0.48 & 0.48 \\
l & 0.59 & 0.60 & 0.59 \\
\hline
\end{tabular}

${ }^{1}$ Treatments: $\mathrm{CON}=$ consistent diet; VAR $=$ daily variation in grass to alfalfa silage ratio; ORR $=$ forage to concentrate ratio varied in 5-d cycles.

${ }^{2}$ Aminoplus (Ag Processing Inc., Omaha, NE).

${ }^{3}$ Contained $125 \mathrm{mg}$ of biotin (DSM Nutritional Products Inc., Parsippany, NJ), $42 \mathrm{mg}$ of Se (sodium selenate), $5.7 \mathrm{~g}$ of Zn from Zn-methionine (Zinpro Corp., Eden Prairie, MN), $1.0 \mathrm{~g}$ of $\mathrm{Cu}$ (copper sulfate), 3,400 IU of vitamin $\mathrm{E}$ (all-rac, $\alpha$-tocopheryl acetate), $153 \mathrm{kIU}$ of vitamin $\mathrm{D}$, and $570 \mathrm{kIU}$ of vitamin $\mathrm{A} / \mathrm{kg}$.

Table 2. Nutrient composition and particle size of diets (DM basis) ${ }^{1}$

\begin{tabular}{|c|c|c|c|c|c|c|}
\hline \multirow[b]{2}{*}{ Item $^{2}$} & \multicolumn{2}{|c|}{$\mathrm{CON}$} & \multicolumn{2}{|c|}{ VAR } & \multicolumn{2}{|c|}{ ORR } \\
\hline & Mean & $\mathrm{SD}$ & Mean & SD & Mean & $\mathrm{SD}$ \\
\hline DM, \% & 60.7 & 1.3 & 60.7 & 2.1 & 60.7 & 2.2 \\
\hline $\mathrm{NDF}, \%$ & 33.2 & 0.9 & 33.1 & 2.2 & 33.3 & 1.7 \\
\hline Forage NDF, $\%$ & 24.7 & 1.2 & 24.6 & 2.3 & 24.9 & 2.4 \\
\hline $\mathrm{CP}, \%$ & 17.3 & 0.3 & 17.3 & 1.0 & 17.3 & 0.3 \\
\hline Ash, $\%$ & 6.93 & 0.2 & 6.91 & 0.3 & 6.94 & 0.3 \\
\hline Lignin, \% & 4.56 & 0.3 & 4.55 & 0.4 & 4.58 & 0.4 \\
\hline $\mathrm{NE}_{\mathrm{L}},{ }^{3} \mathrm{Mcal} / \mathrm{kg}$ & 1.50 & 0.02 & 1.50 & 0.03 & 1.49 & 0.04 \\
\hline $\mathrm{NE}_{\mathrm{L}}-3 \times,{ }^{4} \mathrm{Mcal} / \mathrm{kg}$ & 1.57 & 0.02 & 1.57 & 0.02 & 1.57 & 0.04 \\
\hline Starch, ${ }^{5} \%$ & 27.3 & 0.9 & 27.4 & 0.9 & 27.2 & 2.2 \\
\hline Acid detergent insoluble CP, \% & 1.07 & 0.05 & 1.06 & 0.1 & 1.08 & 0.1 \\
\hline Long-chain fatty acids, $\%$ & 3.28 & 0.05 & 3.29 & 0.07 & 3.27 & 0.1 \\
\hline $\mathrm{Ca}, \%$ & 0.97 & 0.008 & 0.97 & 0.06 & 0.97 & 0.01 \\
\hline $\mathrm{P}, \%$ & 0.40 & 0.003 & 0.40 & 0.007 & 0.40 & 0.006 \\
\hline $\mathrm{K}, \%$ & 1.68 & 0.07 & 1.67 & 0.1 & 1.68 & 0.1 \\
\hline $\mathrm{Mg}, \%$ & 0.21 & 0.003 & 0.21 & 0.008 & 0.21 & 0.004 \\
\hline \multicolumn{7}{|c|}{ Particle size distribution, ${ }^{6} \%$ of as-fed mass } \\
\hline Top screen & 8.1 & 2.1 & 7.2 & 3.2 & 7.8 & 2.3 \\
\hline Middle screen & 35.6 & 2.5 & 35.8 & 2.4 & 36.0 & 3.0 \\
\hline Pan & 56.3 & 1.8 & 57.0 & 4.2 & 56.2 & 3.8 \\
\hline
\end{tabular}

${ }^{1}$ Treatments: $\mathrm{CON}=$ consistent diet; $\mathrm{VAR}=$ daily variation in grass to alfalfa silage ratio; $\mathrm{ORR}=$ forage to concentrate ratio varied in 5 -d cycles.

${ }^{2}$ Mean and standard deviation calculated from daily rations $(\mathrm{n}=84)$ and the corresponding nutrient composition of the silages [i.e., daily DM, 5-d composites NDF, CP, ash, and lignin, and period composites for other nutrients) and concentrate mix (4 period composite samples)].

${ }^{3}$ Calculated (NRC, 2001) using daily DMI and feed composition and period average BW.

${ }^{4}$ Calculated (NRC, 2001) using daily feed composition and a constant discount of $8 \%$.

${ }^{5}$ Starch was assayed in concentrate mixes and was assumed to be $2 \%$ for the silages (feed summary data from DairyOne, Ithaca, NY).

${ }^{6}$ Measured according to Lammers et al. (1996). Mean and standard deviation calculated from 22 samples (selected experimental days). 
Table 3. Composition of silages (DM basis)

\begin{tabular}{|c|c|c|c|c|c|c|}
\hline \multirow[b]{2}{*}{ Item $^{1}$} & \multicolumn{2}{|c|}{ Alfalfa silage A } & \multicolumn{2}{|c|}{ Alfalfa silage B } & \multicolumn{2}{|c|}{ Grass silage } \\
\hline & Mean & $\mathrm{SD}$ & Mean & $\mathrm{SD}$ & Mean & $\mathrm{SD}$ \\
\hline $\mathrm{DM}, \%$ & 44.1 & 2.98 & 50.7 & 3.28 & 43.4 & 2.87 \\
\hline $\mathrm{NE}_{\mathrm{L}},{ }^{2} \mathrm{Mcal} / \mathrm{kg}$ & 1.18 & - & 1.10 & - & 1.01 & - \\
\hline $\mathrm{CP}, \%$ & 18.3 & 0.64 & 21.5 & 1.61 & 11.1 & 0.33 \\
\hline NDF, \% & 45.3 & 1.39 & 44.4 & 2.15 & 64.1 & 2.07 \\
\hline IVNDFD ${ }^{3} \%$ of NDF & 37.4 & 3.08 & 37.2 & 2.38 & 41.8 & 1.73 \\
\hline Acid detergent insoluble CP, \% & 2.11 & 0.21 & 2.90 & 0.36 & 1.81 & 0.12 \\
\hline Lignin, $\%$ & 8.62 & 0.55 & 8.56 & 1.12 & 7.11 & 0.69 \\
\hline Long-chain fatty acids, $\%$ & 2.16 & 0.08 & 1.98 & 0.25 & 1.69 & 0.11 \\
\hline Ash, $\%$ & 9.15 & 0.23 & 12.1 & 0.43 & 8.14 & 0.54 \\
\hline $\mathrm{Ca}, \%$ & 1.08 & 0.02 & 1.11 & 0.06 & 0.56 & 0.03 \\
\hline $\mathrm{P}, \%$ & 0.33 & 0.03 & 0.40 & 0.03 & 0.31 & 0.02 \\
\hline $\mathrm{K}, \%$ & 2.85 & 0.11 & 3.58 & 0.33 & 2.55 & 0.26 \\
\hline $\mathrm{Mg}, \%$ & 0.25 & 0.01 & 0.31 & 0.01 & 0.21 & 0.01 \\
\hline \multicolumn{7}{|c|}{ Particle distribution, ${ }^{4} \%$ of as-fed mass } \\
\hline Top screen & 14.6 & 3.0 & 26.0 & 4.9 & 33.7 & 5.2 \\
\hline Middle screen & 54.2 & 1.6 & 40.4 & 3.9 & 45.9 & 4.2 \\
\hline Pan & 31.2 & 2.1 & 33.7 & 2.5 & 20.4 & 1.9 \\
\hline
\end{tabular}

${ }^{1}$ Mean and standard deviation calculated from 84 samples for DM; 16 samples for CP, NDF, lignin, and ash; 4 samples for long-chain fatty acids; 3 samples for in vitro NDF disappearance and minerals; and 15 samples for particle size.

${ }^{2}$ Calculated with a constant discount of $8 \%$ (NRC, 2001).

${ }^{3}$ In vitro NDF disappearance during a 30-h incubation (Goering and Van Soest, 1970).

${ }^{4}$ Lammers et al. (1996).

\section{Sampling and Analysis}

Silages were sampled daily and assayed for DM by drying for approximately $24 \mathrm{~h}$ at $100^{\circ} \mathrm{C}$ to adjust the diet for changes in silage DM. Day-to-day variation in NDF concentrations of the silages was expected; therefore, NDF concentrations of the silages were monitored and adjustments in diet formulation were done when necessary (Yoder, 2013). Silages were sampled on 2 to 3 $\mathrm{d} /$ wk, dried at $100^{\circ} \mathrm{C}$ for $24 \mathrm{~h}$, and then ground through a 1-mm screen (Wiley mill, Arthur H. Thomas, Philadelphia, PA) and analyzed in duplicate for NDF (Ankom200 Fiber Analyzer, Ankom Technology, Fairport, NY) with sodium sulfite and amylase (Sigma A3306, Sigma Diagnostics, St. Louis, MO). Adjustments of the diet were made when the calculated dietary FNDF concentration changed by $\geq 0.30$ percentage units (DM basis). If the calculated proportion of total silage NDF provided by grass changed by $\geq 0.4$ percentage units, adjustments in diet formulation were also made. These breakpoints are somewhat arbitrary but were decided upon at the start of the experiment and used throughout the entire experiment.

Silages were sampled on 80 of the $84 \mathrm{~d}$ of this experiment and then composited into 16 samples (i.e., 5 -d composites). These samples were dried at $55^{\circ} \mathrm{C}$ for $48 \mathrm{~h}$ and then ground through a 1-mm screen (Wiley mill, Arthur H. Thomas). Samples were analyzed for DM $\left(100^{\circ} \mathrm{C}\right.$ oven for $\left.48 \mathrm{~h}\right)$, in duplicate for NDF (Ankom200 Fiber Analyzer, Ankom Technology) with so- dium sulfite and amylase (A3306, Sigma Diagnostics), ash $\left(600^{\circ} \mathrm{C}\right.$ overnight), and particle size (Lammers et al., 1996). Silage composite samples were also analyzed in duplicate for CP (method 990.03; AOAC International, 2000) and sulfuric acid lignin (Goering and Van Soest, 1970) by Cumberland Valley Analytical Services (CVAS; Hagerstown, MD). Silage composite samples (5-d composites) were further composited into period samples $(\mathrm{n}=4)$ and analyzed by wet chemistry for aciddetergent insoluble CP, 30-h in vitro NDF digestibility (Goering and Van Soest, 1970), and minerals (method 985.01; AOAC International, 2000) by CVAS, and for long-chain FA (Weiss and Wyatt, 2003). Concentrate samples were taken weekly and composited by period $(\mathrm{n}=4)$. Concentrate samples were analyzed for DM, in duplicate for NDF and ash as described above, and for starch (Weiss and Wyatt, 2000). Crude protein and minerals were analyzed as described above by CVAS. Orts were sampled on d $3,6,9,12,15,18$, and 21 of each period and assayed for $\mathrm{DM}\left(100^{\circ} \mathrm{C}\right.$ for $\left.48 \mathrm{~h}\right)$ to calculate DMI. Milk was sampled (a.m. and p.m) on d $2,5,6,7,10,12,13,15,17$, and 20 of each period and assayed for milk fat, true protein, lactose (B2000 Infared Analyzer, Bentley Instruments, Chaska, MN), and MUN (Skalar SAN Plus segmented flow analyzer, Skalar Inc., Norcross, GA) by DHI Cooperative Inc. (Columbus, OH). A subsample of milk (p.m. only) from multiparous cows $(\mathrm{n}=18)$ was taken on $\mathrm{d} 2,5,7,10$, $12,15,17$, and 20 of each period and assayed for FA using a 2-step procedure for methylation (Jenkins, 2000) 


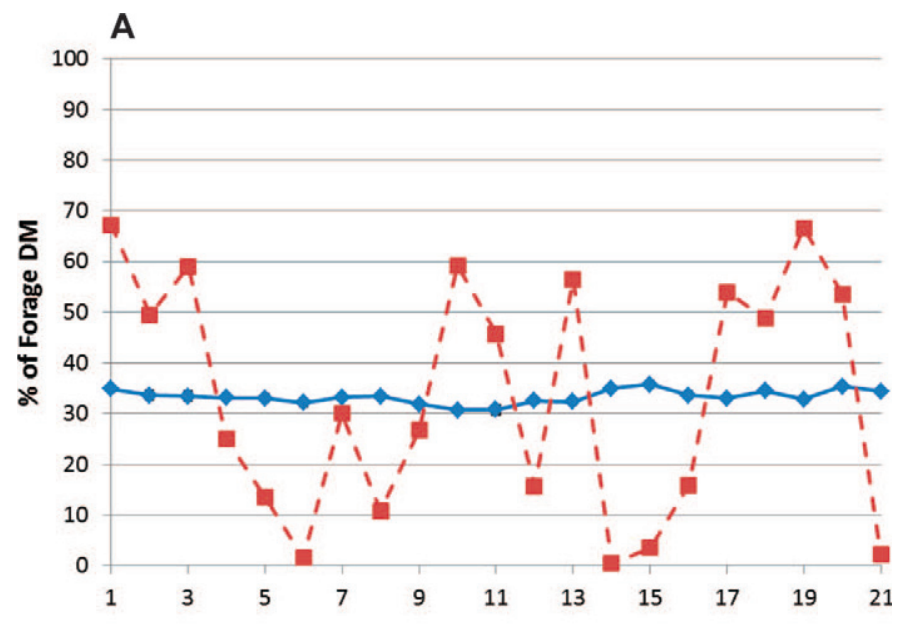

B



Figure 1. Concentrations of grass silage (A) and total forage (B) in the diets. The 3 treatments averaged $66.5 \%$ alfalfa silage and $33.5 \%$ grass silage. The $\mathrm{CV}$ for grass silage inclusion rate for control (CON) and overreacting (ORR) treatments [both designated by solid (blue) line with diamonds] was $8 \%$ and that for variable [VAR treatment; dashed (red) line with squares] was $69 \%$. The 3 treatments averaged $48 \%$ forage. The CV for total forage for CON and VAR [both designated by solid (blue) line with diamonds] was $4 \%$ and that for ORR [dashed (green) line with triangles] was 10\%. Color version available in the online PDF.

with separation by gas-liquid chromatography using a CP-SIL88 capillary column $(100 \mathrm{~m} \times 0.25 \mathrm{~mm} \times 0.2$ $\mu \mathrm{m}$ film thickness; Varian Inc., Palo Alto, CA). The selection of sampling days for milk composition measurements was based on the ORR treatment (Figure 1). Day $2,7,12$, and 17 represent the second day after an abrupt change in forage concentration of the diet, and d $5,10,15$, and 20 were the last days of 5 -d cycles of higher or lower forage concentrations.

\section{Energy Calculations}

The concentrations of $\mathrm{NE}_{\mathrm{L}}$ in daily TMR were calculated (NRC, 2001) using daily DMI for each individual

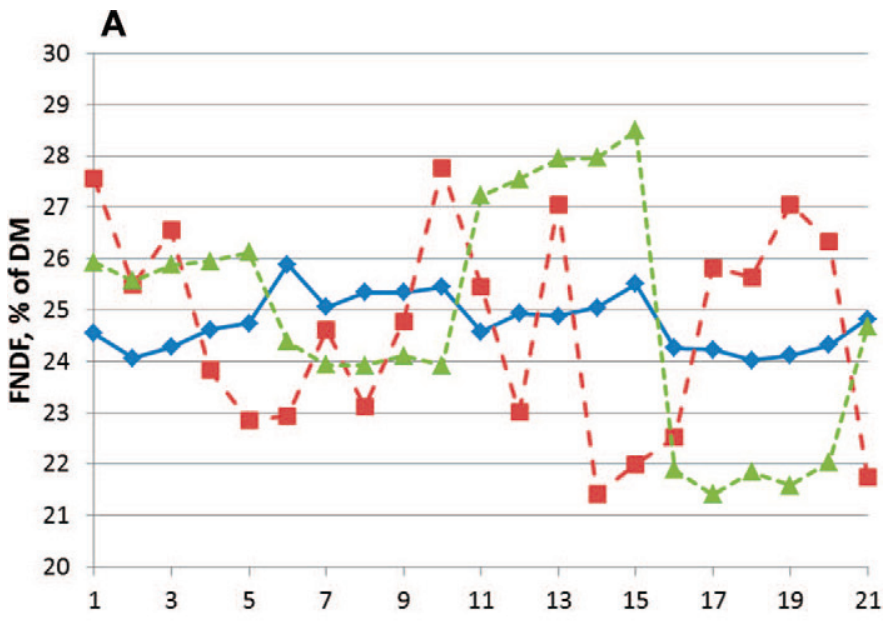

B


Figure 2. Change in forage NDF (FNDF; A), CP (B), and starch (C) concentrations in the diets. The control treatment (solid line, blue diamonds) was consistent from day to day. The variable treatment (dashed line, red squares) changed day to day in grass:alfalfa silage ratio. The overreacting treatment (dashed line, green triangles) changed in the forage to concentrate ratio in 5-d cycles. Color version available in the online PDF. 
cow, diet composition for the given day and cow, and ingredient nutrient composition from the corresponding 5-d composite sample. Daily $\mathrm{NE}_{\mathrm{L}}$ intake was DMI times the calculated $\mathrm{NE}_{\mathrm{L}}$ concentration for each day. Daily milk energy was calculated (NRC, 2001) using daily milk yields for each cow and milk composition data from samples taken on the day closest to the respective day. Maintenance $\mathrm{NE}_{\mathrm{L}}$ requirement was calculated (NRC, 2001) using average BW of each cow-period. Daily $\mathrm{NE}_{\mathrm{L}}$ balance was calculated as daily $\mathrm{NE}_{\mathrm{L}}$ intake - (daily milk $\mathrm{NE}_{\mathrm{L}}$ output + period average daily maintenance $\mathrm{NE}_{\mathrm{L}}$ ).

\section{Adipose Biopsies}

Three squares of multiparous cows ( $\mathrm{n}=9$ cows) were randomly chosen for adipose sampling; however, 1 cow had inadequate subcutaneous fat and was not biopsied. Another cow developed mastitis in 1 period and was not sampled, leaving 8 observations for periods 1 and 2 and 7 observations for period 3. Subcutaneous adipose tissue biopsies from the tail-head region were obtained on d 20 of each period approximately $5 \mathrm{~h}$ after feeding $(0800 \mathrm{~h})$ using a procedure similar to that of Fincham et al. (2009). The biopsy site alternated sides of the tail-head region between periods. Before biopsy, the cow was placed in a chute equipped with a head restraint and the tail-head region was clipped and cleaned with a surgical scrub. Lidocaine $(2 \% ; 10 \mathrm{~mL})$ was used for local anesthesia and a 3- to 4-cm sagittal incision was made in the skin near the gluteal area immediately ventral to the tail head with a \#10 scalpel blade. Subcutaneous adipose tissue (approximately $500 \mathrm{mg}$ ) was excised aseptically using a combination of blunt and sharp dissection with Metzenbaum scissors. Excised samples were immediately evaluated visually and tissue that did not appear to be adipose (fascia) was removed with a scalpel. Remaining adipose tissue was snap frozen in liquid nitrogen and stored at $-80^{\circ} \mathrm{C}$. The incision was then closed with surgical staples and a topical antibiotic ointment was applied. Incision sites were monitored daily for infection (none observed) and skin staples were removed $10 \mathrm{~d}$ later.

\section{RNA Extraction and Real-Time Quantitative PCR}

Comprehensive details are presented in the Supplemental Materials (http://dx.doi.org/10.3168/jds.2013$6724)$. Genes evaluated were abhydrolase domain containing $5(\boldsymbol{A} \boldsymbol{B D H} \boldsymbol{D})$, acetyl-coenzyme A carboxylase < $(\boldsymbol{A} \boldsymbol{C A} \boldsymbol{C A})$, adipose triglyceride lipase $(\boldsymbol{A} \boldsymbol{T} \boldsymbol{G L})$, fatty acid synthase $(\boldsymbol{F A} \boldsymbol{S N})$, fasting-induced adipose factor $(\boldsymbol{F I A F})$, hormone-sensitive lipase $(\boldsymbol{H S L})$, leptin $(\boldsymbol{L} \boldsymbol{E P})$, lipoprotein lipase $(\boldsymbol{L P L})$, stearoyl-CoA desaturase $(\boldsymbol{S C D})$, and thyroid hormone responsive spot 14 (S14). Internal control genes $(\boldsymbol{I} \boldsymbol{C G})$ evaluated were adenylosuccinate lyase $(\boldsymbol{A D S L})$, glyceraldehyde 3-phosphate dehyrodgenase $(\boldsymbol{G A P D H})$, kelch-like ECH-associated protein 1 ( $\boldsymbol{K} \boldsymbol{E} \boldsymbol{A P 1}$ ), ribosomal protein S9 (RPS9), and tripartite motif containing 41 (TRIM41). Based on analysis and using GeNorm software (Vandesompele et al., 2002), ADSL and KEAP1 were the most stable internal control genes. Target genes of interest were normalized to the geometric mean of $A D S L$ and KEAP1 [target gene cycle threshold (Ct) - reference genes $\mathrm{Ct}=\Delta \mathrm{Ct}$; Vandesompele et al. $2002]$. Delta Ct data were then transformed to $2^{(-\Delta \mathrm{Ct})}$ to represent fold differences relative to the reference genes (Velayudhan et al., 2008). The delta Ct data were not normally distributed (Shapiro-Wilk test); therefore, data were $\log (\mathrm{e})$ transformed before statistical analysis. For assay quality control checks, melting curves were analyzed, product sizes were verified using gel electrophoresis, and PCR products were sequenced at Molecular and Cellular Imaging Center (Ohio Agricultural Research and Development Center, Wooster, OH; data not shown).

\section{Statistical Analyses}

One cow during period 3 was diagnosed with clinical mastitis and data for that cow-period were discarded. Dry matter intake data for 3 cows in period 3 were removed because of measurement errors that occurred over several days. The milk production and composition data were not used for another cow for period 3 because of an error in imposing the treatment diet. Milk production, milk composition, and DMI were analyzed with a mixed model with the MIXED procedure of SAS version 9.3 (SAS Institute, 2010). The model included the fixed effects of treatment ( $2 \mathrm{df})$, parity $(1 \mathrm{df})$, the repeated fixed effect of day (20 df), and all 2-way and 3 -way interactions. The random effects of the model included group ( $1 \mathrm{df})$, period (2 df), and cow within group (22 df), and the denominator degrees of freedom for all tests were adjusted using the Kenward-Rogers option. The covariance structure that was used for all analyses was compound symmetry based on the lowest Bayesian information criterion. When the treatment $x$ day interaction was significant $(P \leq 0.10)$, the SLICE option was used to determine on which days of the period $(P \leq 0.10)$ treatment means would be separated using Fisher's protected LSD $(P<0.10)$. A similar model was used for milk FA except that parity was not included in the model (only multiparous cows were sampled) and square within group was included as a 
random effect. The model for analyzing gene expression data included the fixed effects of treatment $(2 \mathrm{df})$, period $(2 \mathrm{df})$, cow $(7 \mathrm{df})$, and period $\times$ treatment interaction $(4 \mathrm{df})$. Period and cow were considered fixed effects because the number of observations was too small to estimate random effects and inference was only for detecting whether differences occurred in these cows. For all measurements, Fisher's protected least significant difference (LSD) test $(P<0.10)$ was used for comparing treatment means. A likelihood-ratio test was used to assess the significance of treatment differences in the variation of DMI and milk yield across days using the GROUP option of the MIXED procedure. Whenever significant, treatment variances were compared using a $\mathrm{z}$-transformation of the differences followed by a $t$-test.

\section{RESULTS AND DISCUSSION}

No parity $\times$ treatment interactions were found and parity effects were as expected (e.g., milk yields were less for primiparous cows) and will not be discussed.

The VAR treatment was designed to evaluate responses to a TMR that was composed of an extremely variable forage. Over the 21-d period, the treatment average NDF and CP concentrations of the forage (alfalfa and grass silage mix) were similar: $51.3 \% \mathrm{NDF}$ and $16.6 \%$ CP. The SD for NDF concentration of the forage mix was 1.4 , the $\mathrm{SD}$ for $\mathrm{CP}$ concentration was 0.6 for the CON and ORR treatments, and were 4.4 and 2.1 for the VAR treatment, respectively. A survey of 8 well-managed, commercial dairy farms in Ohio found that the average day-to-day SD (over a 14-d period) for NDF and CP in hay crop silages were 2.4 and 1.0 (Weiss et al., 2012). The variation in the forage mix for VAR translated into substantial variations in FNDF, NDF, and CP concentrations in the TMR (Table 2, Figure 2).

The ORR treatment was designed to evaluate TMR variability (i.e., the forage to concentrate ratio) induced by unnecessarily changing the diet formulation because of results from errant samples. On d 1, 6, 11, and 16, abrupt changes in forage to concentrate ratio were made, causing abrupt changes in concentrations of starch, NDF, and FNDF. Changing the forage to concentrate ratio for the ORR treatment resulted in similar TMR variation for NDF and FNDF concentrations as the VAR treatment; however, the concentrations followed very different patterns (cyclic vs. random patterns) between the 2 treatments (Table 2, Figure 2 ). In addition, the starch concentration in the TMR for ORR varied substantially compared with CON and VAR (Figure 2) and had a range of 6.1 percentage units over the 21-d period.

\section{Intake}

The 21-d average DMI was greater $(P<0.08)$ for ORR than for the other 2 treatments, but did not differ between cows on CON and VAR (Table 4). Day-today variation in DMI was greater $(P<0.06)$ for cows on VAR $(\mathrm{SD}=0.355)$ than for $\mathrm{CON}(\mathrm{SD}=0.131)$ but variation for ORR $(\mathrm{SD}=0.280)$ was similar to that of the other treatments. The imposed treatments of changing grass and alfalfa concentrations daily or the 5 -d cyclic changes in forage to concentrate ratio caused transient responses, resulting in treatment $\times$ day interactions $(P<0.01)$ for daily DMI (Figure 3$)$. In high-producing cows, physical fill usually limits DMI, and increasing diet FNDF should reduce DMI (Allen, 2000), and increasing the ratio of grass silage to legume silage usually reduces DMI (Moorby et al., 2009). Daily DMI by cows on VAR, however, were lower $(P<0.06)$ for only 4 of the $21 \mathrm{~d}$ in the period compared with CON (Figure 3), even though the percentage grass in the diet was greater for VAR than for CON on 10 of the $21 \mathrm{~d}$. The DMI of VAR was greater $(P<0.04)$ than that of CON on only $1 \mathrm{~d}(\mathrm{~d} 6$; Figure 3$)$, whereas the percentage grass in the diet was substantially lower for VAR than for CON on 9 d. Even feeding a diet with 0 and $4 \%$ of the forage as grass silage for $2 \mathrm{~d}$ (d 14 and 15) did not elicit an increase in DMI by VAR compared with CON ( $P=0.74$ and 0.14 , respectively). Grass particles have greater retention time and slower particle size reduction in the rumen compared with legume particles (Kammes and Allen, 2012). The slower turnover, digestion, and rumen removal of grass silage may have caused a lag effect by requiring several days for the physical filling constraint to be reduced when high grass silage diets were fed. For VAR, daily DMI responded to transient increases in FNDF more than to decreases in FNDF (4 d vs. 1 d) as the negative filling effect of grass silage is likely not confined to $1 \mathrm{~d}$.

Over the entire period, cows on ORR consumed more DMI than cows on CON. During those days when ORR cows were fed higher forage diets, DMI was similar to that of CON. In contrast, on those days when ORR cows were fed lower forage diets, DMI was greater than that of CON (Table 4). Daily DMI by cows on the ORR treatment was never lower than that of cows on the CON treatment during the 21-d period, despite ORR cows being fed diets with greater FNDF concentrations on d 1 to 5 and d 11 to 15 compared with CON (Figure 3). In contrast, DMI by ORR cows was greater than that of CON cows on most days (d 6 through 10 and $d$ 16 to 20) when ORR cows were fed lower FNDF diets than CON cows. The increase in DMI appeared almost immediately after the forage to concentrate ratio was 
Table 4. Effect of treatment on intake and milk production

\begin{tabular}{|c|c|c|c|c|c|c|c|}
\hline \multirow[b]{2}{*}{ Item } & \multicolumn{3}{|c|}{ Treatment $^{1}$} & \multirow[b]{2}{*}{ SEM } & \multicolumn{3}{|c|}{$P$-value ${ }^{2}$} \\
\hline & $\mathrm{CON}$ & VAR & ORR & & Trt & $\mathrm{D}$ & Trt $\times \mathrm{D}$ \\
\hline $\mathrm{DMI}, \mathrm{kg} / \mathrm{d}$ & $24.5^{\mathrm{b}}$ & $24.3^{\mathrm{b}}$ & $25.1^{\mathrm{a}}$ & 0.54 & 0.05 & $<0.01$ & $<0.01$ \\
\hline $\mathrm{NE}_{\mathrm{L}}$ intake, Mcal/d & $36.7^{\mathrm{b}}$ & $36.7^{\mathrm{b}}$ & $37.4^{\mathrm{a}}$ & 0.95 & 0.08 & $<0.01$ & $<0.01$ \\
\hline Milk, kg/d & 42.8 & 43.1 & 43.6 & 1.18 & 0.34 & $<0.01$ & $<0.01$ \\
\hline $\mathrm{ECM}^{3}{ }^{3} \mathrm{~kg} / \mathrm{d}$ & 42.1 & 42.5 & 42.9 & 1.30 & 0.21 & $<0.01$ & $<0.01$ \\
\hline Milk energy, ${ }^{4} \mathrm{Mcal} / \mathrm{d}$ & 28.6 & 28.9 & 29.2 & 0.97 & 0.26 & $<0.01$ & $<0.01$ \\
\hline Milk fat, $\%$ & 3.49 & 3.51 & 3.54 & 0.19 & 0.74 & $<0.01$ & 0.86 \\
\hline Milk fat, $\mathrm{kg} / \mathrm{d}$ & 1.50 & 1.52 & 1.54 & 0.09 & 0.46 & $<0.01$ & $<0.01$ \\
\hline Milk protein, \% & 2.80 & 2.80 & 2.78 & 0.05 & 0.65 & $<0.01$ & 0.18 \\
\hline Milk protein, $\mathrm{kg} / \mathrm{d}$ & 1.20 & 1.21 & 1.21 & 0.04 & 0.64 & $<0.01$ & $<0.01$ \\
\hline Milk lactose, $\%$ & 4.80 & 4.80 & 4.80 & 0.05 & 0.99 & $<0.01$ & 0.46 \\
\hline Milk lactose, $\mathrm{kg} / \mathrm{d}$ & 2.05 & 2.07 & 2.09 & 0.08 & 0.47 & $<0.01$ & $<0.01$ \\
\hline MUN, mg/dL & 10.9 & 11.1 & 10.9 & 0.43 & 0.30 & $<0.01$ & $<0.01$ \\
\hline $\mathrm{NE}_{\mathrm{L}}$ balance, ${ }^{5} \mathrm{Mcal} / \mathrm{d}$ & -1.9 & -2.4 & -1.8 & 1.03 & 0.56 & $<0.01$ & $<0.01$ \\
\hline $\mathrm{BW}, \mathrm{kg}$ & 634 & $63 \overline{5}$ & 632 & 11.7 & 0.20 & NA & NA \\
\hline BW change, $\mathrm{kg} / \mathrm{d}$ & 0.31 & 0.63 & 0.51 & 0.15 & 0.26 & NA & NA \\
\hline BCS & 2.8 & 2.8 & 2.8 & 0.07 & 0.92 & NA & NA \\
\hline BCS change/period & 0.01 & 0.05 & 0.07 & 0.06 & 0.65 & NA & NA \\
\hline \multicolumn{8}{|c|}{$\overline{\mathrm{a}, \mathrm{b}}$ Means within a row with different superscripts differ $(P<0.08)$. } \\
\hline \multicolumn{8}{|c|}{$\begin{array}{l}{ }^{1} \text { Treatments: } \mathrm{CON}=\text { consistent diet; VAR }=\text { daily variation in grass to alfalfa silage ratio; ORR }=\text { forage to } \\
\text { concentrate ratio varied in } 5 \text { - } \mathrm{d} \text { cycles. }\end{array}$} \\
\hline \multicolumn{8}{|c|}{$\begin{array}{l}{ }^{2} \text { Fixed effect of treatment }(\text { Trt }) \text {, day }(\mathrm{D}) \text {, and treatment } \times \text { day interaction }(\text { Trt } \times \mathrm{D}) \text {. Statistical model for } \\
\text { BW and BCS data did not include day or the interaction }(\mathrm{NA}=\text { not applicable). }\end{array}$} \\
\hline \multirow{2}{*}{\multicolumn{8}{|c|}{$\begin{array}{l}{ }^{3} 3.5 \% \text { ECM calculated as }(12.82 \times \mathrm{kg} \text { of fat })+(7.13 \times \mathrm{kg} \text { of protein })+(0.323 \times \mathrm{kg} \text { of milk }) \\
{ }^{4} \text { Calculated from concentrations of true protein, fat, and lactose }(\mathrm{NRC}, 2001) .\end{array}$}} \\
\hline & & & & & & & \\
\hline${ }^{5}$ Calculate & & & & & & & \\
\hline
\end{tabular}

decreased (i.e., d 6 and 16) although statistically significant differences sometimes required a few days to develop (Figure 3). In a previous experiment (Voelker et al., 2002), decreasing the forage concentration in a TMR by 23 percentage units increased DMI by 1.7 $\mathrm{kg} / \mathrm{d}$, and we observed an increase of $1.3 \mathrm{~kg} / \mathrm{d}$ when forage decreased by 12 percentage units (d 16 to d 20). Daily DMI decreased abruptly when the forage to concentrate ratio increased (d 11) but DMI was still not lower than that in CON cows on d 11 through 15 even though the ORR diet had 28\% FNDF compared with $25 \%$ for CON. The lack of a negative DMI response during the ORR cycles of increased forage concentrations may mean that the filling effect of increased FNDF requires several days before it restricts DMI.

The immediate increase in daily DMI for ORR when less forage was fed is in contrast to the very limited (only $1 \mathrm{~d}$ ) increase in daily DMI for VAR when substantially lower FNDF diets were fed. For VAR, when the grass:alfalfa ratio decreased, dietary concentrations of FNDF and NDF also decreased but starch and DM concentrations were largely unaffected. However, for ORR, several dietary components changed when the forage to concentrate ratio decreased, including decreased FNDF and NDF concentrations and increased concentrations of starch and DM. Previously, we showed that an abrupt increase in the DM concentration of a TMR resulted in an immediate 1-d increase in daily DMI but by the second day DMI returned to normal (McBeth et al., 2013). The increase in diet DM concentration when forage to concentrate ratio decreased may have allowed an immediate increase in daily DMI, and then the lower NDF and FNDF allowed the elevated DMI to continue throughout the cycle. Overall, for both treatments, positive responses in daily DMI to decreased concentration of FNDF (among other changes) were much more likely than negative responses in daily DMI to increased FNDF.

\section{Milk Production}

The 21-d average concentrations of milk components and yields of milk, ECM, and milk components were not affected by treatment (Table 4). Day-to-day variation in milk yield was greater $(P<0.04)$ for VAR (SD $=1.482)$ and $\mathrm{ORR}(\mathrm{SD}=1.311)$ than for $\mathrm{CON}(\mathrm{SD}=$ 0.646) but was similar between ORR and VAR. Transient FNDF concentration changes resulted in treatment $\times$ day interactions $(P<0.01)$ for MUN and yields of milk, ECM, and components. However, no treatment $x$ day interaction was observed for milk component concentrations, despite transient changes that included substantial changes in dietary starch and NDF. 

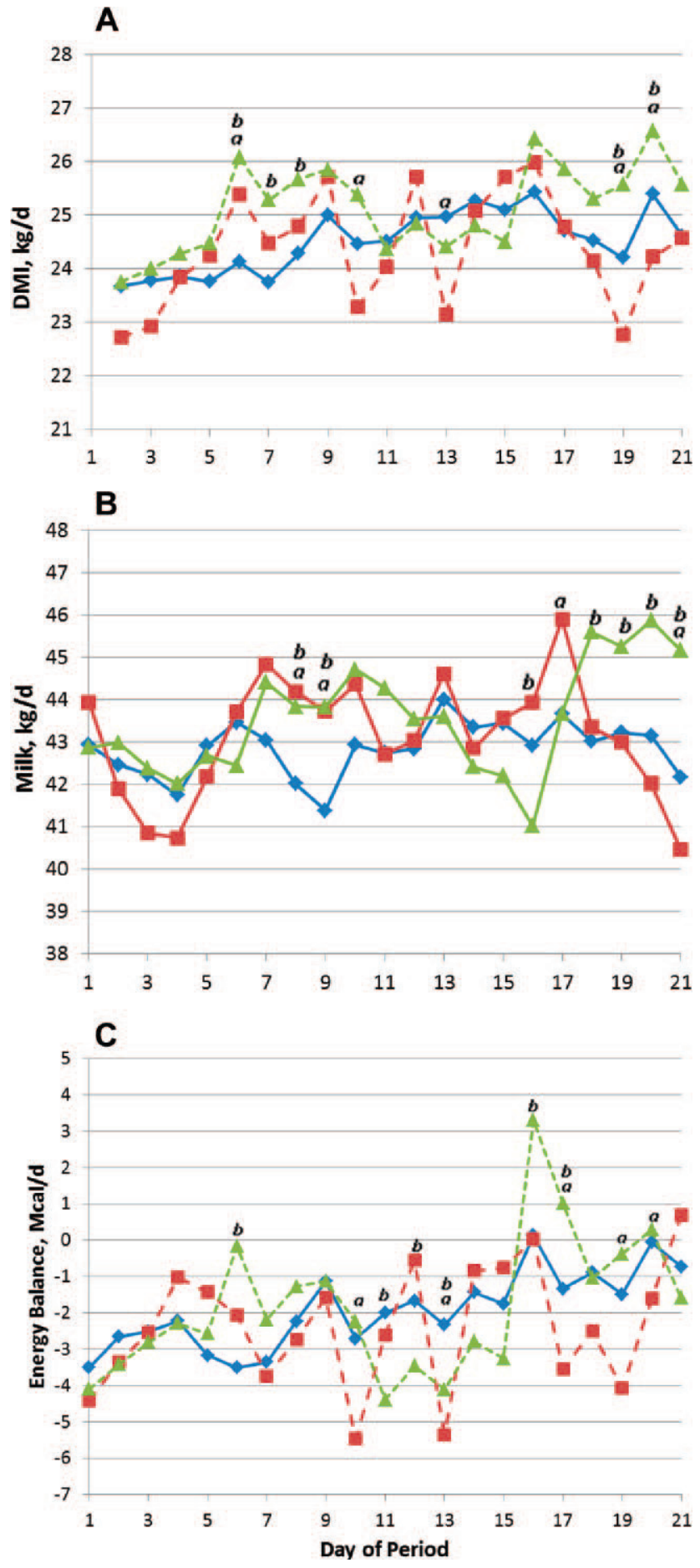

Figure 3. Change in DMI (A), milk yield (B), and $\mathrm{NE}_{\mathrm{L}}$ balance (C) over time. The control (CON) treatment [solid line with (blue) diamonds] was consistent from day to day. The variable (VAR) treatment [dashed line with (red) squares] changed from day to day in grass:alfalfa silage ratio. The overreacting (ORR) treatment [dashed line with (green) triangles] changed in forage to concentrate ratio in 5 -d cycles. A day $\times$ treatment interaction was observed $(P<0.01)$ Treatment comparisons on specific days: $a=\mathrm{CON}$ vs. VAR, $P<0.1$; $b=$ CON vs. ORR, $P<0.1$ (for DMI, milk, and $\mathrm{NE}_{\mathrm{L}}$ balance SEM $=0.66,1.30$, and 1.17 , respectively). Color version available in the online PDF.
Daily milk yield was lower for ORR than for CON on only d 16 of the 21 -d period $(P<0.07$; Figure 3$)$ and VAR had lower daily milk yield than CON only on $\mathrm{d} 21(P<0.07)$. The lower milk yield for VAR followed $4 \mathrm{~d}$ of increased FNDF concentrations, and the lower milk yield for ORR followed $5 \mathrm{~d}$ of increased FNDF concentrations. In contrast, over the 21-d period, milk yields were greater $(P<0.05)$ on $3 \mathrm{~d}$ for VAR and on $6 \mathrm{~d}$ for ORR compared with CON (Figure 3). Milk production by high-producing cows can be quite responsive to dietary differences in the forage to concentrate ratio (Jerred et al., 1990), but in our study, milk yield was more responsive to transient positive diet changes (i.e., lower FNDF concentrations) than to negative diet changes. When diet variation resulted in a higher FNDF ration, negative milk yield responses were less than expected, suggesting that cows are resilient to short-term changes, perhaps via mobilization of adipose tissue. Previously, a 51\% restriction in DMI for 3 wk decreased milk production by only $3 \mathrm{~kg} / \mathrm{d}$, which resulted in a $15 \mathrm{Mcal} / \mathrm{d}$ average $\mathrm{NE}_{\mathrm{L}}$ deficit and a $56-\mathrm{kg}$ BW loss (over $3 \mathrm{wk}$ ), which shows an extreme ability to mobilize body fat (Gross et al., 2011). In another experiment, cows producing $39 \mathrm{~kg} / \mathrm{d}$ of milk were restricted in DMI by $48 \%$, which decreased milk yield by $10 \mathrm{~kg} / \mathrm{d}$ and caused an $\mathrm{NE}_{\mathrm{L}}$ deficit of $8.2 \mathrm{Mcal} / \mathrm{d}$ on $\mathrm{d}$ 4 following feed restriction (Koltes and Spurlock, 2012). In our study, the negative effects of diet variation on milk production were only observed following 4 or $5 \mathrm{~d}$ of feeding higher FNDF diets, which suggests that we should evaluate the effects of negative dietary FNDF changes not in the construct of a 24-h day but over a longer period, perhaps $96 \mathrm{~h}$ or more. Furthermore, realimentation has been shown to occur rapidly following imposed $\mathrm{NE}_{\mathrm{L}}$ intake restriction, which indicates limited negative carryover effects (Gross et al., 2011). Within 1 wk following energy restriction (51\% decreased DMI), cows produced similar milk yields to cows that had no energy restriction (Gross et al., 2011). Within 3 and 4 d, cows that were restricted by $50 \%$ of DMI returned to similar energy balance and milk production, respectively, compared with cows that had no energy restriction (Velez and Donkin, 2005). In our experiment, substantial variation in FNDF concentrations also did not have a negative carryover effect.

Because the grass silage had lower concentrations of $\mathrm{CP}$ than the alfalfa silage, the concentrations of $\mathrm{CP}$ in VAR varied over the 21-d period (Figure 2). For the ORR treatment, dietary starch varied substantially over the 21-d period (Figure 2). Changes in concentrations of these nutrients can affect MUN (Weiss et al., 2009). Concentrations of MUN were greater $(P$ $<0.10$ ) for VAR than for CON on only $1 \mathrm{~d}(\mathrm{~d} 7)$, which was the day after cows fed VAR consumed a 
high protein diet. Cows on ORR had greater MUN $(P<0.10)$ than CON on $\mathrm{d} 12$ and lower MUN on $\mathrm{d} 7$ and 15. The MUN response for ORR did not appear to follow a consistent pattern (being higher than CON during periods with both higher and lower starch concentrations).

\section{Energy Use}

Period average $\mathrm{NE}_{\mathrm{L}}$ balance was not affected by treatment but a treatment $\times$ day interaction was observed $(P<0.01)$. On average, $\mathrm{NE}_{\mathrm{L}}$ balance averaged approximately $-2 \mathrm{Mcal} / \mathrm{d}$ (Table 4), which is equivalent to a loss of approximately $0.4 \mathrm{~kg} / \mathrm{d}$ of BW. However, based on beginning and ending BW of each period, BW change was greater than zero $(P<$ 0.06 ) for all treatments (Table 4$)$. Treatment average changes in BCS were not statistically different from zero (Table 4). Accurately measuring changes in BCS and BW over 21-d periods can be difficult, especially for this experiment, because of the day-to-day changes in DMI induced by dietary treatments. A $1-\mathrm{kg}$ increase in DMI can increase BW by $4 \mathrm{~kg}$ because of gut fill (Chilliard et al., 1991), and gut fill may have changed markedly from day to day because of changes in FNDF. Caution should be exercised when evaluating energy balances within a timeframe of $24 \mathrm{~h}$. The assumption of a diet being entirely converted to milk energy within a set 24 -h period is almost definitely wrong, positive or negative associative effects of the daily diet changes are unknown, which makes estimating diet energy concentrations questionable, and the daily diet changes effect on intermediate metabolism (e.g., lipolysis and protein turnover) is unknown. The NRC (2001) equations used to estimate energy requirements and feed energy are based on experiments in which treatments were fed for weeks or longer (not days).

Cows on VAR had lower calculated $\mathrm{NE}_{\mathrm{L}}$ balance on 5 of the $21 \mathrm{~d}(P<0.10)$, but never had greater daily $\mathrm{NE}_{\mathrm{L}}$ balance than CON (Figure 3). Cows on ORR had lower $\mathrm{NE}_{\mathrm{L}}$ balance on $4 \mathrm{~d}(P \leq 0.10)$ and higher $(P<0.10)$ $\mathrm{NE}_{\mathrm{L}}$ balance on 3 of the $21 \mathrm{~d}$ compared with CON. The days on which ORR $\mathrm{NE}_{\mathrm{L}}$ balance was greater than that of CON occurred at the beginning of the cycles when ORR cows were fed lower forage diets (d 6,16 , and 17). For VAR, on days when calculated $\mathrm{NE}_{\mathrm{L}}$ intake was greater than $\mathrm{CON}$, additional energy was likely partitioned to milk and on days when $\mathrm{NE}_{\mathrm{L}}$ intake was less than CON, milk energy output was usually maintained, resulting in calculated $\mathrm{NE}_{\mathrm{L}}$ losses from the body. Increased $\mathrm{NE}_{\mathrm{L}}$ intake by high-producing cows was partitioned entirely to milk but less so for moderateproducing cows, as some of the additional $\mathrm{NE}_{\mathrm{L}}$ intake went toward body tissue replenishment (Voelker et al.,
2002). Other studies have shown that cows have the ability to mobilize tissue $\mathrm{NE}_{\mathrm{L}}$ and have severe energy deficits following $3 \mathrm{wk}, 5 \mathrm{~d}, 7 \mathrm{~d}$, or $7 \mathrm{~d}$, respectively, of feed restriction (Carlson et al., 2006; Moyes et al., 2009; Gross et al., 2011; Koltes and Spurlock, 2012). The partitioning of increased $\mathrm{NE}_{\mathrm{L}}$ intake to milk $\mathrm{NE}_{\mathrm{L}}$ on days when lower FNDF diets were fed while using body $\mathrm{NE}_{\mathrm{L}}$ to maintain milk on days when high FNDF diets were fed would result in cows on VAR and ORR likely losing BW and BCS if the duration of treatment was long enough.

\section{Gene Expression}

No treatment or period $\times$ treatment interactions were observed for adipose tissue gene mRNA abundance (Table 5). Expression of $A C A C A$ and $L E P$ were not reported because of a limited number of samples and problems with repeatability. Sampling of adipose tissue occurred on d 20 (approximately $5 \mathrm{~h}$ after feeding), and calculated $\mathrm{NE}_{\mathrm{L}}$ balance on d 19 was $2.6 \mathrm{Mcal}$ less for the VAR cows $(P<0.01)$ and 1.1 Mcal numerically greater for ORR cows $(P=0.23)$ compared with CON. On the sampling day (d 20), $\mathrm{NE}_{\mathrm{L}}$ balance was 1.6 Mcal less for $\operatorname{VAR}(P=0.09)$ and 0.3 Mcal numerically greater for ORR $(P=0.71)$. In general, expression of genes associated with lipogenesis ( $L P L, F A S N, S C D$, and S14) and lipolysis (ATGL, FIAF, and HSL) was similar across all treatments on d 20. The numerical differences of increased expression for the lipogenesis genes $(S C D$ and $S 14)$ by the ORR cows compared with the CON cows agree with previous research. Increasing $\mathrm{NE}_{\mathrm{L}}$ balance and $\mathrm{NE}_{\mathrm{L}}$ intake in cows increased $S C D$ and S14 mRNA abundance (Harvatine et al., 2009; Loor, 2010); 144 is highly responsive to changes in $\mathrm{NE}_{\mathrm{L}}$ balance and is an important regulator for transcription of enzymes related to lipogenesis (Cunningham et al., 1998). Severe feed restriction (i.e., $48 \%$ of DMI) for $4 \mathrm{~d}$ significantly increased expression of FIAF in dairy cows (Koltes and Spurlock, 2012), but the limited change we observed for VAR suggests that this gene is less responsive to the imposed short-term (day) moderate energy restriction. Although our experiment was not designed with gene expression change as the primary measurement, and thus we did not have the necessary power to detect statistical changes, we did observe numeric increases for most genes (especially lipogenic-related genes) in response to diet variation and possibly shortterm changes in $\mathrm{NE}_{\mathrm{L}}$ balance (Table 5). The numerical increases in gene expression lead to speculation that increased variation in $\mathrm{NE}_{\mathrm{L}}$ balance requires greater lipolytic and lipogenic enzyme transcription, translation, and turnover. Further research is needed to test this hypothesis. 
Table 5. Effect of treatment on relative mRNA abundance [expressed as $\log 2^{(-\Delta \mathrm{Ct})}$ ] of lipogenic and lipolytic genes in subcutaneous adipose tissue

\begin{tabular}{|c|c|c|c|c|c|c|c|c|}
\hline \multirow[b]{2}{*}{ Gene $^{1}$} & \multicolumn{3}{|c|}{ Treatment $^{2}$} & \multirow[b]{2}{*}{ SEM } & \multicolumn{4}{|c|}{$P$-value ${ }^{3}$} \\
\hline & $\mathrm{CON}$ & VAR & ORR & & Trt & Cow & Per & Per $\times \operatorname{Trt}$ \\
\hline \multicolumn{9}{|l|}{ Lipogenic } \\
\hline$L P L$ & 4.06 & 4.84 & 4.61 & 0.63 & 0.61 & 0.15 & 0.03 & 0.53 \\
\hline$F A S N$ & 3.39 & 3.54 & 3.90 & 0.69 & 0.86 & 0.11 & 0.02 & 0.24 \\
\hline$S C D$ & 4.49 & 5.02 & 5.70 & 0.79 & 0.62 & 0.23 & 0.03 & 0.48 \\
\hline S14 & 6.52 & 6.39 & 7.40 & 0.74 & 0.58 & 0.09 & 0.01 & 0.20 \\
\hline \multicolumn{9}{|l|}{ Lipolytic } \\
\hline$A T G L$ & 4.31 & 4.47 & 4.47 & 0.35 & 0.92 & 0.03 & 0.28 & 0.15 \\
\hline ABHD5 & 3.75 & 4.17 & 4.05 & 0.23 & 0.44 & 0.25 & 0.02 & 0.32 \\
\hline$H S L$ & 2.00 & 3.10 & 2.66 & 0.77 & 0.18 & 0.38 & 0.18 & 0.37 \\
\hline FIAF & 2.75 & 2.91 & 2.72 & 0.18 & 0.69 & 0.12 & 0.09 & 0.05 \\
\hline
\end{tabular}

${ }^{1} L P L=$ lipoprotein lipase; $F A S N=$ fatty acid synthase; $S C D=$ stearoyl-CoA desaturase; $S 14=$ thyroid hormone responsive SPOT 14; $A B H D 5=$ abhydrolase domain containing 5; $A T G L=$ adipose triglyceride lipase; $H S L=$ hormone-sensitive lipase; FIAF = fasting-induced adipose factor

${ }^{2}$ Treatments: $\mathrm{CON}=$ consistent diet; $\mathrm{VAR}=$ daily variation in grass to alfalfa silage ratio; ORR $=$ forage to concentrate ratio varied in 5-d cycles.

${ }^{3}$ Statistical model included fixed effect of treatment (Trt), period (Per), period $\times$ treatment interaction $($ Per $\times$ Trt), and cow (Cow).

\section{Milk Fatty Acids}

Generally, average milk FA concentrations were not affected by treatment $(P>0.10$; Table 6$)$. Only 2 fatty acids, iso-16:0 and cis-9,trans-11 CLA, differed $(P<0.08)$ between treatments, and the differences were quite small. However, a day $\times$ treatment interaction was observed for most FA. Substantial changes in dietary carbohydrate fractions related to ruminal acidosis, particularly for ORR, had only a small effect on FA markers for milk fat depression and subclinical ruminal acidosis. A treatment effect on the concentration of C18:1 trans-10 was found for only $1 \mathrm{~d}$ (ORR was greater than $\mathrm{CON}$ on $\mathrm{d} 20 ; P=0.04$ ), and no treatment by day interaction was observed for trans10,cis-12 CLA concentrations. Those $2 \mathrm{FA}$ are positively associated with SARA and milk fat depression (Kalscheur et al., 1997; Peterson et al., 2003; Colman et al., 2010). The concentration of iso-C16 was lower for ORR than for CON on d $20(P=0.05)$ and is negatively related to trans-10 C18:1 (Colman et al., 2010). The concentration of dietary forage was reduced and starch concentration increased from d 16 to 20 for ORR compared with CON. Previously, the concentration of trans-10 C18:1 increased to a greater extent following $7 \mathrm{~d}$ of feeding an acidosis-type diet versus $2 \mathrm{~d}$ of feeding (Colman et al., 2010), which would agree with our response being observed only following $5 \mathrm{~d}$ of reduced dietary forage (d 20 of period). In contrast, trans-10 C18:1 changed almost immediately $(1 \mathrm{~d})$ when cows were subjected to oscillating dietary fat concentrations (Weiss et al., 2013) but the average concentrations of trans-10 C18:1 were much higher in that experiment (4.2 vs. $1.4 \%$ of milk FA).
Odd- and branched-chain fatty acids (OBCFA) are only synthesized by rumen bacteria and can be used as markers of rumen microbial populations ( $\mathrm{Wu}$ and Palmquist, 1991; Vlaeminck et al., 2006; Fievez et al., 2012). We observed treatment $\times$ day interactions for iso-C14:0, iso-C15:0, and iso-C16:0, which are primarily synthesized by rumen cellulolytic bacteria and are positively associated with acetate production and negatively related to subclinical acidosis (Vlaeminck et al., 2006; Colman et al., 2010). Milk from cows on VAR had increased iso-C14:0 (Figure 4) and iso-C16:0 on d 12 and $20(P<0.09)$ and increased iso-C15:0 on d $20(P=$ $0.02)$ compared with CON. These increases in OBCFA were preceded by 2 and $3 \mathrm{~d}$ of feeding diets with higher grass silage and FNDF concentrations compared with CON. The ORR also had increased iso-C14:0 on every sampling day when diet forage was higher than CON (d 2, 5, 12, and 15; $P<0.01 ;$ Figure 4). Concentrations of iso-C15:0 and iso-C16:0 for ORR followed a similar trend, although not as pronounced, compared with CON. Concentrations of OBCFA appeared to be responsive to increased dietary fiber, suggesting the ability for populations of cellulolytic bacteria to increase within 1 to $2 \mathrm{~d}$ following a dietary change. Both VAR and ORR had increased concentrations of C15:0 on $1 \mathrm{~d}$ each (d 7 and d 20, respectively; $P<0.04$ ) following 3 $\mathrm{d}$ and $5 \mathrm{~d}$ of a lower fiber diet, respectively, compared with CON. The ORR had increased C17:0 concentrations on $\mathrm{d} 15(P=0.04)$ during $5 \mathrm{~d}$ of a higher forage diet compared with CON. Linear odd-chain fatty acids, C15:0 and C17:0, are formed through elongation of propionate or valerate and de novo synthesis can occur by rumen bacteria, the mammary gland, and other tissues (Vlaeminck et al., 2006; Dewhurst et al., 
Table 6. Effect of treatment on milk FA (\% of total FA)

\begin{tabular}{|c|c|c|c|c|c|c|c|}
\hline \multirow[b]{2}{*}{$\mathrm{FA}^{1}$} & \multicolumn{3}{|c|}{ Treatment $^{2}$} & \multirow[b]{2}{*}{ SEM } & \multicolumn{3}{|c|}{$P$-value ${ }^{3}$} \\
\hline & $\mathrm{CON}$ & VAR & ORR & & Trt & $\mathrm{D}$ & $\operatorname{Trt} \times \mathrm{D}$ \\
\hline $4: 0$ & 3.94 & 3.99 & 3.92 & 0.14 & 0.38 & $<0.01$ & 0.40 \\
\hline $6: 0$ & 2.57 & 2.64 & 2.58 & 0.07 & 0.36 & $<0.01$ & 0.99 \\
\hline $8: 0$ & 1.34 & 1.38 & 1.35 & 0.04 & 0.51 & $<0.01$ & 0.84 \\
\hline 10:0 & 2.83 & 2.90 & 2.86 & 0.17 & 0.76 & $<0.01$ & 0.17 \\
\hline 12:0 & 3.09 & 3.15 & 3.12 & 0.20 & 0.81 & $<0.01$ & 0.08 \\
\hline iso-13:0 & 0.02 & 0.02 & 0.02 & 0.0008 & 0.71 & $<0.01$ & 0.06 \\
\hline anteiso-13:0 & 0.08 & 0.08 & 0.08 & 0.0064 & 0.87 & $<0.01$ & 0.09 \\
\hline $13: 0$ & 0.09 & 0.10 & 0.10 & 0.015 & 0.11 & $<0.01$ & 0.76 \\
\hline iso-14:0 & 0.09 & 0.09 & 0.09 & 0.0053 & 0.11 & $<0.01$ & $<0.01$ \\
\hline $14: 0$ & 10.18 & 10.23 & 10.21 & 0.41 & 0.97 & $<0.01$ & 0.07 \\
\hline iso-15:0 & 0.18 & 0.18 & 0.18 & 0.0033 & 0.86 & $<0.01$ & $<0.01$ \\
\hline anteiso-15:0 & 0.37 & 0.38 & 0.38 & 0.011 & 0.49 & $<0.01$ & $<0.01$ \\
\hline $14: 1$ & 0.94 & 0.94 & 0.96 & 0.08 & 0.85 & $<0.01$ & $<0.01$ \\
\hline $15: 0$ & 0.83 & 0.82 & 0.84 & 0.05 & 0.65 & $<0.01$ & $<0.01$ \\
\hline iso-16:0 & 0.22 & 0.23 & 0.23 & 0.0092 & 0.08 & 0.02 & $<0.01$ \\
\hline $16: 0$ & 25.48 & 25.49 & 25.45 & 0.42 & 0.99 & $<0.01$ & $<0.01$ \\
\hline iso-17:0 & 0.36 & 0.35 & 0.35 & 0.013 & 0.26 & $<0.01$ & $<0.01$ \\
\hline 16:1 and anteiso-17:0 & 1.79 & 1.75 & 1.77 & 0.08 & 0.64 & 0.09 & 0.94 \\
\hline $17: 0$ & 0.63 & 0.63 & 0.63 & 0.011 & 0.65 & $<0.01$ & $<0.01$ \\
\hline $17: 1$ & 0.22 & 0.22 & 0.21 & 0.02 & 0.58 & $<0.01$ & 0.23 \\
\hline 18:0 & 11.41 & 11.67 & 11.63 & 0.36 & 0.27 & $<0.01$ & $<0.01$ \\
\hline trans -6 and $8,18: 1$ & 0.61 & 0.59 & 0.61 & 0.03 & 0.59 & $<0.01$ & 0.15 \\
\hline trans $-9,18: 1$ & 0.46 & 0.46 & 0.45 & 0.04 & 0.85 & $<0.01$ & 0.43 \\
\hline trans-10, 18:1 & 1.38 & 1.24 & 1.33 & 0.20 & 0.59 & $<0.01$ & 0.02 \\
\hline trans-11, 18:1 & 1.58 & 1.50 & 1.57 & 0.13 & 0.14 & $<0.01$ & 0.05 \\
\hline trans-12, 18:1 & 0.63 & 0.63 & 0.65 & 0.03 & 0.44 & $<0.01$ & $<0.01$ \\
\hline cis-9, $18: 1$ & 22.75 & 22.50 & 22.55 & 0.90 & 0.84 & $<0.01$ & 0.01 \\
\hline cis-11, $18: 1$ & 0.62 & 0.59 & 0.60 & 0.04 & 0.35 & $<0.01$ & 0.96 \\
\hline $18: 2$ & 3.59 & 3.57 & 3.53 & 0.09 & 0.54 & $<0.01$ & 0.14 \\
\hline 20:0 & 0.19 & 0.19 & 0.19 & 0.005 & 0.36 & $<0.01$ & $<0.01$ \\
\hline $20: 1$ & 0.13 & 0.13 & 0.13 & 0.005 & 0.65 & 0.11 & $<0.01$ \\
\hline $18: 3$ & 0.61 & 0.60 & 0.61 & 0.01 & 0.66 & $<0.01$ & $<0.01$ \\
\hline CLA, cis-9,trans-11 ${ }^{4}$ & 0.77 & 0.72 & 0.75 & 0.05 & 0.08 & $<0.01$ & 0.60 \\
\hline CLA, trans -10, cis -12 & 0.028 & 0.026 & 0.027 & 0.0026 & 0.43 & 0.13 & 0.69 \\
\hline $\mathrm{LCFA}^{5}$ & 44.8 & 44.4 & 44.7 & 1.08 & 0.88 & $<0.01$ & $<0.01$ \\
\hline \multicolumn{8}{|c|}{${ }^{1}$ Number of carbons:number of double bonds. } \\
\hline \multicolumn{8}{|c|}{$\begin{array}{l}{ }^{2} \text { Treatments: } \mathrm{CON}=\text { consistent diet; } \mathrm{VAR}=\text { daily variation in grass to alfalfa silage ratio; ORR }=\text { forage to } \\
\text { concentrate ratio varied in } 5 \text {-d cycles. }\end{array}$} \\
\hline \multicolumn{8}{|c|}{$\begin{array}{l}{ }^{3} \text { Statistical model included the fixed effect of treatment }(\text { Trt }) \text {, day }(\mathrm{D}) \text {, and treatment } \times \text { day interactions }(\text { Trt } \\
\times \mathrm{D}) \text {. }\end{array}$} \\
\hline \multicolumn{8}{|c|}{${ }^{4} \mathrm{CLA}=$ conjugated linoleic acid } \\
\hline${ }^{5} \mathrm{LCFA}=$ sum of fatty & & & & & & & \\
\hline
\end{tabular}

2007; French et al., 2012). Milk fat C15:0 concentrations are positively correlated with plasma propionate (Massart-Leen et al., 1983; French et al., 2012) and rumen propionate production (Bhagwat et al., 2012). Milk fat C17:0 concentrations are positively related to plasma propionate and adipose mobilization (Craninx et al., 2008; French et al., 2012).

Concentrations of C18:0 increased in milk from cows on VAR (d 2, 12, and 20; $P<0.04$ ) and ORR (d 12 and 15; $P<0.05)$ when a greater FNDF diet was fed compared with CON (Figures 2 and 4). Cows mobilizing body fat have increased C18:0 in milk (Stoop et al., 2009). In our experiment during times of prolonged feeding of lower FNDF diets, $\mathrm{NE}_{\mathrm{L}}$ intake increased and C18:0 milk concentrations decreased (Figures 1, 3, and 4). During prolonged periods of feeding higher FNDF diets, $\mathrm{NE}_{\mathrm{L}}$ intake decreased and $\mathrm{C} 17: 0$ and $\mathrm{C} 18: 0$ increased, indicating adipose mobilization.

\section{CONCLUSIONS}

Day-to-day and 5-d cyclic dietary FNDF variation had no cumulative negative effect on DMI, milk yields, milk components, or feed efficiency over a 21-d period. Cow responses to transient increases in FNDF concentration were minor: milk yields decreased on only 1 d each for VAR and ORR compared with CON. In contrast, responses to transient decreases in FNDF concentration were greater in frequency and occurred more rapidly. Milk FA markers of adipose mobilization and rumen microbial populations changed in response to changes in dietary FNDF and DMI and indicate 
A

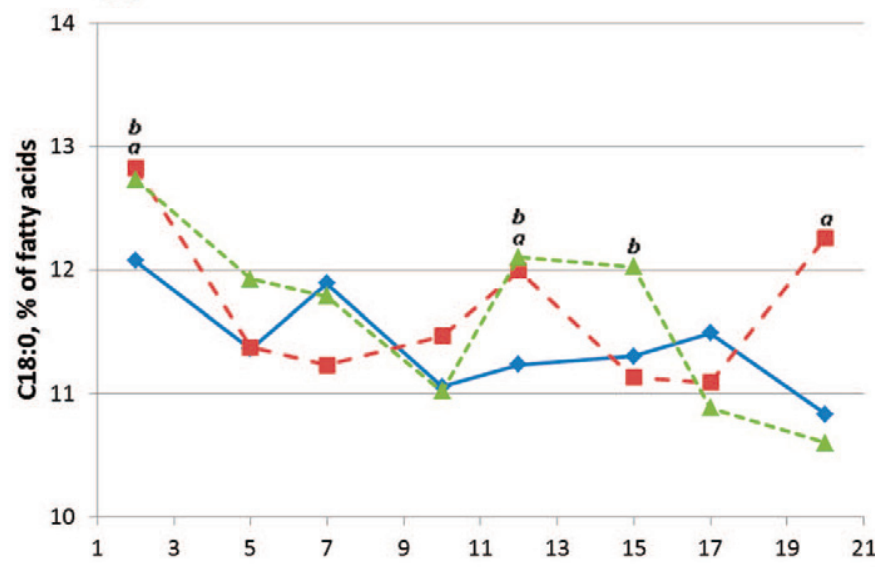

B

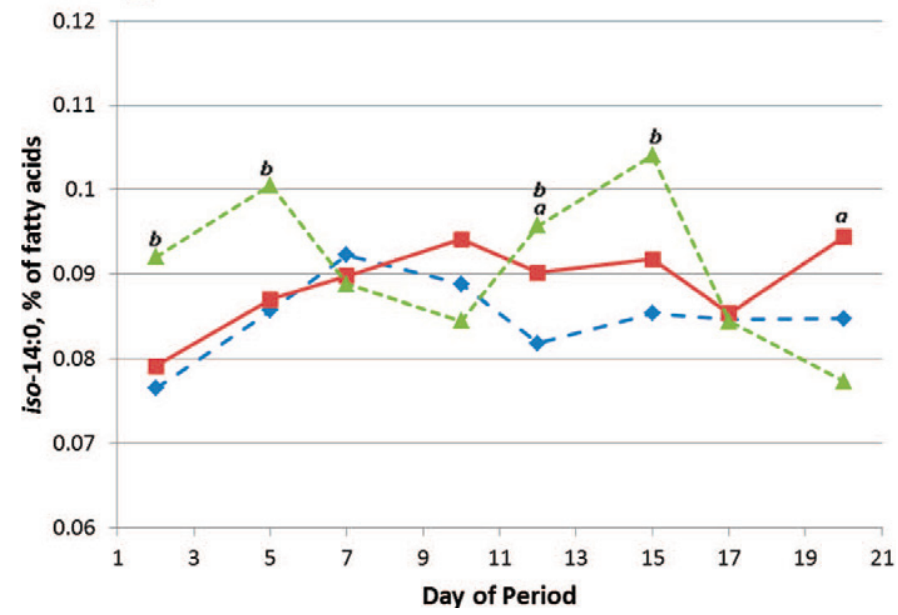

Figure 4. Change in concentrations (\% of total milk FA) of C18:0 (A) and iso-14:0 (B) over time. The control (CON) treatment [solid line with (blue) diamonds] was consistent from day to day. The variable (VAR) treatment [dashed line with (red) squares] changed from day to day in grass:alfalfa silage ratio. The overreacting (ORR) treatment [dashed line with (green) triangles] changed in forage to concentrate ratio in 5 -d cycles. A day $\times$ treatment interaction was observed $(P<0.01)$. Treatment comparisons on specific days: $a=\mathrm{CON}$ vs. VAR, $P<0.1 ; b=\mathrm{CON}$ vs. ORR, $P<0.1$ (for C18 and iso-14:0, $\mathrm{SEM}=0.43$ and 0.006 , respectively). Color version available in the online PDF.

that short-term mobilization of body fat allowed cows to maintain milk production when high FNDF diets reduced feed and $\mathrm{NE}_{\mathrm{L}}$ intake. Altogether, the cows appeared to have the ability to dampen the response to repeated short-term bouts ( 1 to $3 \mathrm{~d}$ ) of higher FNDF diets and reduced $\mathrm{NE}_{\mathrm{L}}$ intake.

\section{ACKNOWLEDGMENTS}

This project was supported by National Research Initiative Competitive Grant no. 2009-55206-05242 from the USDA National Institute of Food and Agriculture (Washington, DC).

\section{REFERENCES}

Allen, M. S. 2000. Effects of diet on short-term regulation of feed intake by lactating dairy cows. J. Dairy Sci. 83:1598-1624.

AOAC International. 2000. Official Methods of Analysis. Vols. 1 and 2. 17th ed. AOAC International, Gaithersburg, MD.

Barmore, J., and G. Bethard. 2005. Performance monitoring of dairy nutrition and feeding. Pages 11-29 in Proc. Tri-State Dairy Nutr. Conf., Ft. Wayne, IN. Ohio State University, Columbus.

Bhagwat, A. M., B. De Baets, A. Steen, B. Vlaeminck, and V. Fievez. 2012. Prediction of ruminal volatile fatty acid proportions of lactating dairy cows based on milk odd- and branched-chain fatty acid profiles: New models, better predictions. J. Dairy Sci. 95:3926-3937.

Carlson, D. B., N. B. Litherland, H. M. Dann, J. C. Woodworth, and J. K. Drackley. 2006. Metabolic effects of abomasal L-carnitine infusion and feed restriction in lactating Holstein cows. J. Dairy Sci. 89:4819-4834.

Chilliard, Y., M. Cisse, R. Lefaivre, and B. Remond. 1991. Body composition of dairy cows according to lactation stage, somatotropin treatment, and concentrate supplementation. J. Dairy Sci. 74:3103-3116.

Cole, N. A., L. W. Greene, F. T. McCollum, T. Montgomery, and K. McBride. 2003. Influence of oscillating dietary crude protein concentration on performance, acid-base balance, and nitrogen excretion of steers. J. Anim. Sci. 81:2660-2668.

Colman, E., W. B. Fokkink, M. Craninx, J. R. Newbold, B. De Baets, and V. Fievez. 2010. Effect of induction of subacute ruminal acidosis on milk fat profile and rumen parameters. J. Dairy Sci. 93:4759-4773.

Craninx, M., A. Steen, H. Van Laar, T. Van Nespen, J. Martin-Tereso, B. De Baets, and V. Fievez. 2008. Effects of lactation stage on the odd- and branched-chain milk fatty acids of dairy cattle under grazing and indoor conditions. J. Dairy Sci. 91:2662-2677.

Cunningham, B. A., J. T. Moncur, J. T. Huntington, and W. B. Kinlaw. 1998. "Spot 14" protein: A metabolic integrator in normal and neoplastic cells. Thyroid 8:815-825.

Dewhurst, R. J., J. M. Moorby, B. Vlaeminck, T. Van Nespen, and V. Fievez. 2007. Apparent recovery of duodenal odd- and branchedchain fatty acids in milk. J. Dairy Sci. 90:1775-1780.

Fievez, V., E. Colman, J. M. Castro-Montoya, I. Stefanov, and B. Vlaeminck. 2012. Milk odd- and branched-chain fatty acids as biomarkers of rumen function-An update. Anim. Feed Sci. Technol. 172:51-65.

Fincham, J. R., J. P. Fontenot, W. S. Swecker, J. H. Herbein, S. J. P. Neel, G. Scaglia, W. M. Clapham, and D. R. Notter. 2009. Fatty acid metabolism and deposition in subcutaneous adipose tissue of pasture-and feedlot-finished cattle. J. Anim. Sci. 87:3259-3277.

French, E. A., S. J. Bertics, and L. E. Armentano. 2012. Rumen and milk odd- and branched-chain fatty acid proportions are minimally influenced by ruminal volatile fatty acid infusions. J. Dairy Sci. 95:2015-2026.

Goering, H. K., and P. J. Van Soest. 1970. Forage fiber analysis. Page 379-379 in Agric. Handbook No. 379. Agricultural Research Service-US Department of Agriculture, Washington, DC.

Gross, J., H. A. van Dorland, R. M. Bruckmaier, and F. J. Schwarz. 2011. Performance and metabolic profile of dairy cows during a lactational and deliberately induced negative energy balance with subsequent realimentation. J. Dairy Sci. 94:1820-1830.

Harvatine, K. J., J. W. Perfield II, and D. E. Bauman. 2009. Expression of enzymes and key regulators of lipid synthesis is upregulated in adipose tissue during CLA-induced milk fat depression in dairy cows. J. Nutr. 139:849-854.

Jenkins, T. C. 2000. Feeding oleamide to lactating Jersey cows. 1. Effects on lactation performance and milk fatty acid composition. J. Dairy Sci. 83:332-337. 
Jerred, M. J., D. J. Carroll, D. K. Combs, and R. R. Grummer. 1990. Effects of fat supplementation and immature alfalfa to concentrate ratio on lactation performance of dairy cattle. J. Dairy Sci. $73: 2842-2854$.

Kalscheur, K. F., B. B. Teter, L. S. Piperova, and R. A. Erdman. 1997. Effect of fat source on duodenal flow of trans-C18:1 fatty acids and milk fat production in dairy cows. J. Dairy Sci. 80:2115-2126.

Kammes, K. L., and M. S. Allen. 2012. Rates of particle size reduction and passage are faster for legume compared with cool-season grass, resulting in lower rumen fill and less effective fiber. J. Dairy Sci. 95:3288-3297.

Koltes, D. A., and D. M. Spurlock. 2012. Adipose tissue angiopoietin-like protein 4 messenger RNA changes with altered energy balance in lactating Holstein cows. Domest. Anim. Endocrinol. 43:307-316.

Lammers, B. P., D. R. Buckmaster, and A. J. Heinrichs. 1996. A simple method for the analysis of particle sizes of forage and total mixed rations. J. Dairy Sci. 79:922-928.

Loor, J. J. 2010. Genomics of metabolic adaptations in the peripartal cow. Animal 4:1110-1139.

Massart-Leën, A. M., E. Roets, G. Peeters, and R. Verbeke. 1983. Propionate for fatty acid synthesis by the mammary gland of the lactating goat. J. Dairy Sci. 66:1445-1454.

McBeth, L. R., N. R. St-Pierre, D. E. Shoemaker, and W. P. Weiss. 2013. Effects of transient changes in silage dry matter concentration on lactating dairy cows. J. Dairy Sci. 96:3924-3935.

Moorby, J. M., M. R. F. Lee, D. R. Davies, E. J. Kim, G. R. Nute, N. M. Ellis, and N. D. Scollan. 2009. Assessment of dietary ratios of red clover and grass silages on milk production and milk quality in dairy cows. J. Dairy Sci. 92:1148-1160.

Moyes, K. M., J. K. Drackley, J. L. Salak-Johnson, D. E. Morin, J. C. Hope, and J. J. Loor. 2009. Dietary-induced negative energy balance has minimal effects on innate immunity during a Streptococcus uberis mastitis challenge in dairy cows during midlactation. J. Dairy Sci. 92:4301-4316.

NRC. 2001. Nutrient Requirements of Dairy Cattle. 7th rev. ed. Natl. Acad. Press, Washington, DC.

Peterson, D. G.. E. A. Matitashvili, and D. E. Bauman. 2003. Diet-induced milk fat depression in dairy cows results in increased trans-10, cis-12 CLA in milk fat and coordinate suppression of mRNA abundance for mammary enzymes involved in milk fat synthesis. J. Nutr. 133:3098-3102.

SAS Institute. 2010. SAS/STAT 9.3 User's Guide. SAS Inst. Inc., Cary, NC.

St-Pierre, N. R., and B. Cobanov. 2007. A model to determine the optimal sampling schedule of diet components. J. Dairy Sci. 90:5383-5394.
Stoop, W. M., H. Bovenhuis, J. M. Heck, and J. A. van Arendonk. 2009. Effect of lactation stage and energy status on milk fat composition of Holstein-Friesian cows. J. Dairy Sci. 92:1469-1478.

Vandesompele, J., K. De Preter, F. Pattyn, B. Poppe, N. Van Roy, A. De Paepe, and F. Speleman. 2002. Accurate normalization of real-time quantitative RT-PCR data by geometric averaging of multiple internal control genes. Genome Biol. 3:H0034.

Velayudhan, B. T., K. M. Daniels, D. P. Horrell, S. R. Hill, M. L. McGilliard, B. A. Corl, H. Jiang, and R. M. Akers. 2008. Development histology, segmental expression, and nutritional regulation of somatotropic axis genes in small intestine of preweaned dairy heifers. J. Dairy Sci. 91:3343-3352.

Velez, J. C., and S. S. Donkin. 2005. Feed restriction induces pyruvate carboxylase but not phosphoenolpyruvate carboxykinase in dairy cows. J. Dairy Sci. 88:2938-2948.

Vlaeminck, B., V. Fievez, S. Tamminga, R. J. Dewhurst, A. Van Vuuren, D. De Brabander, and D. Demeyer. 2006. Milk odd- and branched-chain fatty acids in relation to the rumen fermentation pattern. J. Dairy Sci. 89:3954-3964.

Voelker, J. A., G. M. Burato, and M. S. Allen. 2002. Effects of pretrial milk yield on responses of feed intake, digestion, and production to dietary forage concentration. J. Dairy Sci. 85:2650-2661.

Weiss, W. P., D. E. Shoemaker, L. R. McBeth, and N. R. St-Pierre. 2013. Effects on lactating dairy cows of oscillating dietary concentrations of unsaturated and total long-chain fatty acids. J. Dairy Sci. 96:506-514.

Weiss, W. P., D. E. Shoemaker, L. R. McBeth, P. S. Yoder, and N. R. St-Pierre. 2012. Within-farm variation in nutrient composition of feeds. Pages 103-140 in Proc. Tri-State Dairy Nutr. Conf., Ft. Wayne, IN. Ohio State University, Columbus.

Weiss, W. P., N. R. St-Pierre, and L. B. Willett. 2009. Varying type of forage, concentration of metabolizable protein, and source of carbohydrate affects nutrient digestibility and production by dairy cows. J. Dairy Sci. 92:5595-5606.

Weiss, W. P., and D. J. Wyatt. 2000. Effect of oil content and kernel processing of corn silage on digestibility and milk production by dairy cows. J. Dairy Sci. 83:351-358.

Weiss, W. P., and D. J. Wyatt. 2003. Effect of dietary fat and vitamin $\mathrm{E}$ on $\alpha$-tocopherol in milk from dairy cows. J. Dairy Sci. 86:3582-3591.

Wu, Z., and D. L. Palmquist. 1991. Synthesis and biohydrogenation of fatty acids by ruminal microorganisms in vitro. J. Dairy Sci. 74:3035-3046.

Yoder, P. S. 2013. Effects of forage quality variation on lactating dairy cows. MS Thesis. The Ohio State University, Columbus. 